\title{
Analysis of the influence of external environmental factors on the development of high-tech enterprises
}

\author{
Elizaveta Dubitskaya ${ }^{1, *}$, and Olga Tcukanova ${ }^{1}$ \\ ${ }^{1}$ ITMO University 197101, Kronverksky pr, 49, St. Petersburg, Russia
}

\begin{abstract}
The main external environmental factors that influence the development of high-tech enterprises are identified in the article. As a result of the research, the interaction system of the external factors was developed, the correlation matrix was constructed, regression analysis was performed. This paper provides the necessity of practical application of the system of interaction of the external factors to increase the innovative activity of the high-tech enterprise.
\end{abstract}

\section{Introduction}

Today we are witnessing an intensive development of the economic growth, which is confirmed by the growth of scientific and technological progress, increasing competition in local and world markets, and the total growth in high-tech production capacity. The gradual transition to the new technological structure is taking place now, the economy based on knowledge is developing all over the world. Companies need to adapt to the global environmental changes, it is necessary to develop and modify process management models, to taking into account all aspects of economic activity.

The object of research is a high-tech enterprise. The main purpose of the study is to develop a system of indicators of the external factors that affect to the innovation development of high-tech enterprises. The results of the research will allow to quantify the influence of the external factors on the development of high-tech enterprises. This is necessary to develop an effective management model and to achieve the strategic and tactical goals of the organization.

\section{Materials and methods}

As a result of the research was launched the following hypothesis: the development and practical application of management methods of high-tech enterprises, developed on the basis of the analysis of the external environmental factors and their influence on each other, as well as the object of research based on scientific approaches of process management, will increase the effectiveness of scientific-research and development in general, as well as

\footnotetext{
*Corresponding author: dubitskaya.elizaveta@gmail.com
} 
lead to increased competitiveness of Russian high-tech products on the Russian and international market.

The main scientific research contradiction is that in the development of methodology for the management of enterprises of different industries do not always take into account the systemic impact of the external environmental factors, not examined the relationship between factors and not evaluated their impact on each other.

The main criteria for evaluating the reliability of the results of the research are based on government statistics (including the R\&D statistics) of the Russian economy, and independent analytical collections. On the basis of these criteria was conducted quantitative assessment of the influence of external factors on the development of high-tech enterprise, through a correlation-regression analysis

\section{Results}

A high-tech enterprise is an economic entity operating in the sector of high-tech industries, possessing innovative activity, performing research and development, both at the expense of its own and borrowed funds, managing on the basis of innovative methods and technologies, and corresponding to the generally recognized in the world practice requirements and criteria [1].

Analysis of the essence of a high-tech enterprise leads to the identification of the following features:

1. The use of advanced production technologies;

2. The presence of technical know-how, innovative development;

3. The commercialization of the results of own research and development;

4. High qualification of scientific and production employees;

5. The high rate of changes, products improvement, technologies, focus on new research;

6. Maintaining a close relationship with the academic environment, carrying out fundamental research.

External factors, which include the economic, political, technological, social and international factors, are the resources for enterprise management. An analysis of the macroeconomic environment represents one of the tools of forming an effective model of high-tech enterprise.

Authors consider the external factors that have the greatest impact on the development of the enterprises that produce high-tech products below.

1. Economic factors have a strong impact on all business processes of high-tech enterprises. Economic factors are determined by the levels of development of national and world economy, market institutions, the welfare of the population, the unemployment rate, taxation, inflation, labor productivity.

The R\&D demand increases with improvement in the economic situation in the country. To stimulate the R\&D activities requires the maintenance of the maximum possible demand for high-tech The state should support the demand for scientific products to stimulate the development of the R\&D activities. For this purpose it is necessary to increase the level of budgetary allocations for research funding and increase the share of R\&D in the appropriations [2]. It should be noted that the cost of research and development over the last ten years in Russia increased by 12 times and in 2016 amounted to 943815,2 million rubles, the volume of innovative goods and services rose 6.8 times (3723693,442 million in 2016) compared to 2005 there has been an increase in the number of organizations performing research and development (9.2 percent of organizations in the 2016) [3].

Analysis of the economic factors that influence on the development of high-tech enterprises helps: 
- to ensure the competitiveness in the world and local markets of high-tech products;

- to increase the value added high-tech products and high productivity;

- to maintenance of the necessary high-tech production resources.

2. Political factors

Political factors influence on the development of high-tech industries and the most is regulated by the Science and Technology Russian Public Policy. The research environment is a complex of academic, industry and educational institutions, as well as the scientific grant funds, the state scientific centers and innovation-technological centers, industrial parks, who had already achieved some success in innovation activity [4].

3. Technological factors

Technological factors have the most influence on the development on the Russian economy and high-tech enterprises. The level of R\&D activities in Russia is quite high, it confirmed the achievements in the field of optics and quantum electronics, physical and technical acoustics, chemical physics, pharmaceutical, microelectronics.

Analysis of the technological factors influencing on the development of high-tech enterprises helps to:

- achieve the best technological parameters (for example, energy intensity, material intensity);

- implement the innovation information and telecommunication technologies both in the manufacturing process and the management models;

- implement the information security system for the protection the commercial manufacturing and management secrets;

- achieve the highest efficiency of the resource using.

\section{Social factors}

Social factors are the important integral part of the external environment.

The R\&D Staff directly affects to the creation of innovative high-tech developments. The commercial success of the high technologies introduction to the market depends on the vocational training level. In 2016 in Russia R\&D Staff were involved 722291 people, of whom 108388 people have academic degrees [3]. Also, a great attention is paid to the research education - the number of universities, research centers has increased more than two times since 2000 [3]. The scientific potential of scientific personnel is one of the strongest strategic advantages in Russia. Therefore, the creation of a strong, harmonious social environment in society as a whole, and at enterprises in particular is an important strategic task.

\section{International factors}

Intensive development of the innovation economy promotes the expansion of foreign exchange operations, an in-depth examination of international experience of creation and commercialization of high technology. To create the competitive product it is necessary to investigate not only domestic but also international experience, to take part in international scientific conferences and exhibitions of high technology, to close deals with international counterparts. An analysis of the external economic factors would allow:

- to share the results of the scientific and technical results with international counterparties;

- contribute to the strengthening of the political, scientific and technical relations;

- to contribute to the formation of international concerns, with the participation of Russian high-tech companies;

- to strengthen the process of import substitution of high technologies in the country;

- to contribute to the growth of the export of high technology.

The content of external factors that influence on the development of high-tech companies for more details revealed in Table 1 below. The authors suggest to rank the factors on the level of significance in the formation model of enterprise management. The 
authors suggest that there are different impacts for each of the selected factors on the development of high-tech enterprise

Table 1. External environmental factors that influence on the development high-tech enterprises.

\begin{tabular}{|c|c|c|c|c|}
\hline $\begin{array}{l}\text { External } \\
\text { environment } \\
\text { al factors }\end{array}$ & $\begin{array}{l}\text { Significan } \\
\text { ce level }\end{array}$ & $\begin{array}{l}\text { Group of } \\
\text { indicators }\end{array}$ & $\begin{array}{l}\text { Significan } \\
\text { ce level }\end{array}$ & Key indicators \\
\hline \multirow{10}{*}{$\begin{array}{l}\text { Economic } \\
\text { factors }\end{array}$} & \multirow{10}{*}{$30 \%$} & \multirow{3}{*}{ The tax indicators } & \multirow{3}{*}{$25 \%$} & Tax relief \\
\hline & & & & The tax rate multiplier effect \\
\hline & & & & Tax rates \\
\hline & & \multirow{3}{*}{$\begin{array}{l}\text { Economic growth } \\
\text { rates }\end{array}$} & \multirow{3}{*}{$25 \%$} & GDP figures \\
\hline & & & & Rate of inflation \\
\hline & & & & Rate of unemployment \\
\hline & & \multirow{4}{*}{$\begin{array}{l}\text { Indicators of } \\
\text { industrial market } \\
\text { development }\end{array}$} & \multirow{4}{*}{$50 \%$} & $\begin{array}{l}\text { Level of productivity in high- } \\
\text { technology industry }\end{array}$ \\
\hline & & & & $\begin{array}{l}\text { Rate of growth productivity in } \\
\text { high-technology industry }\end{array}$ \\
\hline & & & & High-tech market capacity \\
\hline & & & & $\begin{array}{l}\text { Level of demand for high-tech } \\
\text { products }\end{array}$ \\
\hline \multirow{6}{*}{$\begin{array}{l}\text { Political } \\
\text { factors }\end{array}$} & \multirow{6}{*}{$15 \%$} & \multirow{3}{*}{$\begin{array}{l}\text { Intellectual } \\
\text { property } \\
\text { protection }\end{array}$} & \multirow{3}{*}{$65 \%$} & Number of patents granted \\
\hline & & & & $\begin{array}{l}\text { IT security and protection of } \\
\text { trade secrets }\end{array}$ \\
\hline & & & & Quantity of know-how \\
\hline & & \multirow{3}{*}{ Power of the state } & \multirow{3}{*}{$45 \%$} & Monetary policy \\
\hline & & & & Innovation development policy \\
\hline & & & & Funding of the R\&D process \\
\hline \multirow{6}{*}{$\begin{array}{l}\text { Technologic } \\
\text { al factors }\end{array}$} & \multirow{6}{*}{$30 \%$} & \multirow{2}{*}{$\begin{array}{l}\text { R\&D } \\
\text { performance }\end{array}$} & \multirow[t]{2}{*}{$50 \%$} & $\begin{array}{l}\text { The number of articles in } \\
\text { scientific journals (Scopus/Web } \\
\text { of Science) }\end{array}$ \\
\hline & & & & $\begin{array}{l}\text { Developing and using advanced } \\
\text { production technologies }\end{array}$ \\
\hline & & \multirow{4}{*}{$\begin{array}{l}\text { Hich-tech product } \\
\text { commercialization } \\
\text { rate }\end{array}$} & \multirow{4}{*}{$50 \%$} & Innovative activity rate \\
\hline & & & & $\begin{array}{l}\text { Costs on technological } \\
\text { innovation }\end{array}$ \\
\hline & & & & $\begin{array}{l}\text { Existence of the strong material } \\
\text { and technical infrasructure }\end{array}$ \\
\hline & & & & Degree of IT management \\
\hline \multirow{7}{*}{$\begin{array}{l}\text { Social } \\
\text { factors }\end{array}$} & \multirow{7}{*}{$15 \%$} & \multirow{4}{*}{$\begin{array}{l}\mathrm{R} \& \mathrm{D} \text { human } \\
\text { resources }\end{array}$} & \multirow{4}{*}{$70 \%$} & $\begin{array}{l}\text { Number of personnel employein } \\
\text { in R\&D process }\end{array}$ \\
\hline & & & & $\begin{array}{l}\text { Salary level for personnel } \\
\text { employed in R\&D process }\end{array}$ \\
\hline & & & & $\begin{array}{l}\text { Community attitudes to } \\
\text { scientific and technological } \\
\text { progress }\end{array}$ \\
\hline & & & & $\begin{array}{l}\text { Researchers allocation in the } \\
\text { Scientific areas }\end{array}$ \\
\hline & & \multirow{3}{*}{$\begin{array}{l}\text { Consumer } \\
\text { preferences }\end{array}$} & \multirow{3}{*}{$30 \%$} & $\begin{array}{l}\text { Customs, cultures and traditions } \\
\text { of the people. }\end{array}$ \\
\hline & & & & $\begin{array}{l}\text { Exploring the root demand for } \\
\text { high-tech products }\end{array}$ \\
\hline & & & & $\begin{array}{l}\text { Population structure, } \\
\text { demographic situation }\end{array}$ \\
\hline International & $10 \%$ & International & $50 \%$ & Participation in international \\
\hline
\end{tabular}




\begin{tabular}{|l|l|l|l|}
\hline factors & marketing & & exhibitions \\
\hline & & & $\begin{array}{l}\text { Obtainig grants/subsidies } \\
\text { Implementation of the search } \\
\text { partners, equipment suppliers, } \\
\text { distributors }\end{array}$ \\
\hline & & $\begin{array}{l}\text { The analysis of the world } \\
\text { market of technologies }\end{array}$ \\
\cline { 3 - 4 } & $\begin{array}{l}\text { Foreign trade } \\
\text { operations }\end{array}$ & $50 \%$ & $\begin{array}{l}\text { The development of high } \\
\text { technology exports/imports }\end{array}$ \\
\hline & $\begin{array}{l}\text { Attracting foreign direct } \\
\text { investment for the development } \\
\text { of high-tech enterprises }\end{array}$ \\
\hline
\end{tabular}

To identify the most important factors requires a quantitative assessment of their influence. Each factor can be described several quantitative indicators. The indicators that influence of external factors on the development of high-tech industries of the Russian economy for the period 2000 - 2016 can be formalized through building the correlation matrix of interaction, where the output $(Y)$ is the number of the used advanced production technologies in the year.

The list of factors that determine on the impact on the output $Y$ below:

$x_{1}$ - the internal costs of research and development, the state sector, million rubles;

$x_{2}$ - the internal costs of research and development, the business sector, million rubles;

$x_{3}$ - the dynamics of the GDP, at constant prices, million rubles;

$x_{4}$ - number of publications of the Russian authors in scientific journals indexed in SCOPUS and Web of Science, units;

$x_{5}$ - the number of issued patents in the Russian Federation, units;

$x_{6}$ - the dynamics of inflation, $\%$;

$x_{7}$ - The number of personnel engaged in research and development, units.

It is necessary to define the closeness between factors, and select the factors with the greatest influence on the output $Y$ (the number of used advanced production technologies in the year). For this purpose, it is necessary to build a matrix of correlation coefficients.

Table 2. Matrix of the correlation coefficients.

\begin{tabular}{|l|l|l|l|l|l|l|l|l|}
\hline & $Y$ & $x_{1}$ & $x_{2}$ & $x_{3}$ & $x_{4}$ & $x_{5}$ & $x_{6}$ & $x_{7}$ \\
\hline$Y$ & 1 & 0,87 & 0,87 & 0,78 & 0,61 & 0,91 & $-0,72$ & $-0,96$ \\
\hline$x_{1}$ & 1 & 0,99 & 0,94 & 0,87 & 0,86 & $-0,58$ & $-0,9$ \\
\hline$x_{2}$ & & & 1 & 0,96 & 0,86 & 0,88 & $-0,59$ & $-0,9$ \\
\hline$x_{3}$ & & & & 1 & 0,83 & 0,84 & $-0,55$ & $-0,83$ \\
\hline$x_{4}$ & & & & & 1 & 0,54 & $-0,23$ & $-0,62$ \\
\hline$x_{5}$ & & & & & & 1 & $-0,75$ & $-0,94$ \\
\hline$x_{6}$ & & & & & & & 1 & 0,78 \\
\hline$x_{7}$ & & & & & & & & 1 \\
\hline
\end{tabular}

The analysis of the correlation matrix allows to draw the following conclusions:

- calculations show that if $|r|<0,4973$ the correlation coefficient should be considered insignificant, the analysis of the correlation matrix shows that all factors strongly enough linked to the sign and are significant;

- the number of the used advanced production technologies most closely connected with the indicators $x_{5}$ - the number of issued patents in the Russian Federation; and $x_{7}$ - the number of personnel engaged in research and development process. So growth of the level 
of significance of the impact of technological and social factors will experience the intensive development of high-tech enterprises.

Further it is necessary to compose the regression equation:

$$
y_{t}=797995+0,239 x_{5}+0,805 x_{7}
$$

The determination coefficient $\left(R^{2}=0,92\right)$ is close to unity, so the quality of the model constructed is high enough. The coefficient of determination shows that the regression equation by $92 \%$ explains the behavior of the characteristic and means that the random deviations are $8 \%$.

The adequacy of the regression equation is checked by Fisher's F-criterion and the Student's test. The calculated value of F-statistics $=82.25$ at a critical value of 2.12. Because the calculated value exceeds the critical value $(82.25>2.12)$, then the regression equation is adequate. Student's T-criterion for $x_{5}=2.34, x_{7}=4,1$, the table value of the Student's test is 2,179 . Since the T-criterion of coefficients and exceeds the tabulated value, one can conclude that the coefficients of the regression equation are significant. Thus, the regression equation can be considered significant.

\section{Discussion}

An analysis of the system of indicators that influence the development of hi-tech enterprise allows to draw the following conclusions:

- all of the external factors are in close relationship with each other, the most strong relationship between the costs of research and development in both the public and the business sector. If the state increases the financing of research and development, this entails an increase in the cost to the business sector, consequently increasing innovative activity in the country as a whole;

- growth of the significance level the of technological and social factors will lead to intensive development of high-tech enterprises.

Explain the regression equation (1) can be read as follows: the increase in the number of issued patents in Russia for one year, the number of advanced production technologies will grow by an average of $23 \%$ with a fixed number of personnel engaged in research and development. When the increase in the number of personnel engaged in research and development, the number of advanced production technologies will grow by an average of $80 \%$ with a fixed number of personnel engaged in research and development. Thus confirmed the high level of importance of social and technological factors of an environment of high-tech enterprise.

\section{Conclusions}

As a result of the research we have developed a system for assessing the impact of the external environmental factors at each other. The main goal for the high-tech enterprise management is to identify all extarnal factors which influence on the the economic activity and then rank and select the factors based on the degree of relevance to the core business processes, and then conduct correlation-regression analysis. The advantage of the system is its flexibility, high-tech companies carry out business activities in different industries, produce different size and level of technological equipment, external environment which is characterized by a unique external factors, characteristic for a specific production. The practical application of the developed system of indicators of the external environment factors will form significal part the management model, based both on the domestic scientific potential of the organization and on the use of the most significant related 
external factors that will increase the competitiveness of high-tech production, to form an effective strategic plans, regular adjustment of the system of interaction in the overall management model, the enterprise will increase the effectiveness of research and development as well as stimulate intensive economic growth enterprises and of the Russian economy.

\section{References}

1. S. Maksin, Innovations 4, 32 (2009)

2. P.V. Savchenko, National Economy (Economist, Moscow, 2005)

3. N. Gorodnikova, L. Gokhberg, K. Ditkovsky, Indicators of Science: 2018 (HSE, Moscow, 2018)

4. A. Asaul, Economic Revival of Russia 1, 4 (2007)

5. I. Eliseeva, M. Yuzbashev, General theory of statistics (Finance and Statistics, Moscow, 2004)

6. O. Tsukanova, E. Torosyan, M. Morozova, 4rd International Multidisciplinary Scientific Conference on Social Sciences and Arts, SGEM 5, 165 (2017)

7. O. Tsukanova, E. Dubitskaya, Journal of Legal and Economic Studies 1, 152 (2018)

8. R. Cooper, S. Edgett, Kleinschmidt E. R\&D Management 4, 361 (2011)

9. S. Shane, Handbook of Technology and Innovation Management (Wiley-Blackwell, New Jersey, 2010)

10. A. Zakrzewska-Bielawska, Recent advances in management, marketing, finances $\mathbf{4 2}$, 93 (2012)

11. G. Pisano, Creating an R\&D Strategy (Harvard Business School, Boston, 2012) 